\title{
The Dis-Integration of Administrative Law: A Comment on Shapiro
}

\author{
E. Donald Elliott, Jr. $†$
}

Martin Shapiro's proposal to break "administrative discretion" down into smaller units is a step in the right direction, but it does not go far enough. ${ }^{1}$ In this Comment, I propose an alternative view which I call the "dis-integration" of administrative law. ${ }^{2}$ I do not mean that administrative law no longer exists, but rather that it is gradually becoming a more diffuse and less powerful force in the law.

I first consider the general enterprise of inventing new legal concepts. (This point is not directed exclusively at Shapiro's Article, but relates to others in the Symposium as well.) I then focus on the concept of administrative discretion and its relationship to judicial review. The heart of my Comment describes what I take to be the disagreement between Shapiro and me as to the future of administrative law. Shapiro predicts both greater emphasis on "technocracy" and an expansion of court control over administrative discretion. ${ }^{3} \mathrm{I}$ believe that these two tendencies conflict and that increased reliance on forms of expertise other than judge-made law will accelerate the "dis-integration" of administrative law. Finally, I consider the implications of this trend for the professional role of lawyers.

$†$ Associate Professor of Law, Yale University.

1. There are two competing models of administrative discretion in Shapiro's Article. One, which dominates the first half of the Article, uses the traditional procedural categories of administrative law (adjudication, rulemaking, and informal action). The other model consists of the eight functional categories that Shapiro presents in the second half of his Article. Implicitly, these more refined categories reflect the process I call the "dis-integration" of administrative law. Categories such as Shapiro's "thematic statutes" are still too broad and formalistic, however. Agencies that specialize in highvolume, low-cost decisionmaking, for example, resemble only vaguely those that make scientific risk assessments.

2. See H. SPENCER, FIRST PRINCIPLES §95, at 258 (6th ed. 1902) ("All things are growing or decaying, accumulating matter or wearing away, integrating or disintegrating. . . . Both the quantity of matter contained in an aggregate and the quantity of motion contained in it, increase or decrease; and increase or decrease of either is an advance towards greater diffusion or greater concentration."); see also T. KUHN, THE STRUCTURE OF SCIENTIFIC REVOLUTTONS 77-91 (2d ed. 1970) (rise and fall of "paradigms"); E. LEVI, AN INTRODUCTION TO LEGAL REASONING 8-9 (1949) (describing three stages in life cycle of legal concept, last being "breakdown" as legal development has proceeded so far that concept is no longer a useful organizing idea); $c$. J. RIFKIN, ENTROPY: A NEW WORLD VIEW 33-43 (1980) (describing as "law of entropy" the principle of thermodynamics by which all organized structures tend to disintegrate); .

3. Shapiro, Administrative Discretion: The Next Stage, 92 YALE L.J. 1487 (1983). 
I sympathize with Shapiro's ambition to create a new conceptual scheme for analyzing administrative discretion. My problem is seeing how we persuade other people to adopt Shapiro's terminology. As arresting as phrases like Shapiro's "technocrat-democratic cycle"s may be, I suspect that Jerry Mashaw is going to go right on drawing his box charts, ${ }^{5}$ Bruce Ackerman will continue talking about the "Coasean universe," and Robert Rabin will keep discussing oscillations and historical epochs." Many of us are speaking to the same issues, but unless we speak the same language, our dialogue will become a dangling conversation leading nowhere.

The mark of a science is that a person of ordinary intelligence in one generation can understand the insights of a genius in the prior generation. The ability to assemble insights so that they build on one another has helped to give science and oher organized bodies of knowledge their extraordinary power. ${ }^{8}$ By comparison, legal scholarship is an extremely disorganized body of knowledge. Legal scholars continually discover, lose, and reinvent in new words the insights of their predecessors. ${ }^{9}$ The cause, at least in part, is the lack of a shared frame of reference. Here, our brothers and sisters who are doing "law-and-economics" have a great advantage. They may not be right, but at least they share a theory which enables them to communicate with one another (although not always with the rest of us). ${ }^{10}$

Bruce Ackerman maintains that the business of legal scholarship is to

4. Id. at $1495-96$.

5. See Mashaw, "Rights" in the Federal Administrative State, 92 YALE L.J. 1129, 1158 (1983).

6. See Ackerman, Foreword: Law in an Activist State, 92 YALE L.J. 1083, 1101 (1983).

7. See Rabin, Legitimacy, Discretion, and the Concept of Rights, 92 YALE L.J. 1174, 1174 (1983).

8. See L. THOMAS, THE LIVES OF A CELL 115-20 (1974) (role of planning in scientific research).

9. See Elliott, Holmes and Evolution: Legal Process as Artificial Intelligence, 13 J. LEGAL STUD. 113,144 (1984) (contrasting attitude toward tradition in legal scholarship with attitudes in other disciplines).

10. In recognizing that economic theory is being used as a communications channel, I do not mean to imply that it is value free. See, e.g., Kennedy, Cost-Benefit Analysis of Entitlement Programs: $A$ Critique, 33 STAN. L. REV. 387, 388 (1981) (economic allocation theories entail value judgments); Rizzo, The Mirage of Efficiency, 8 HOFSTRA L. REV. 641 (1980).

On the value of uniformity, see A UNIFORM SYSTEM OF GITATION i, iv (13th ed. 1981) (purpose of uniform system is to ensure that authorities can be identified and found by readers). As a hypothetical "modest proposal," law review editors might try to impose a requirement that scholars express their ideas as improvements or corrections to the paradigms that already exist in the literature, rather than each proposing his or her own new model and inventing his or her own private language. This "reform" may be impractical, and it is probably too weak to overcome the incentive for novelty created by perceptions of the tenure standard at some law schools. My proposal does, however, illustrate the theoretical point that the efficiency of collective scholarship would be increased by saving each individual reader the burden of translating and relating scholars' ideas to one another. 
invent innovative "reconceptualizations" of bodies of law. "If such conceptual creations are to have more than purely aesthetic value, they must be usable by someone for some purpose. It remains among the open questions what uses, if any, there might be for Shapiro's "tentative" scheme for describing administrative discretion. ${ }^{12}$ It is premature, therefore, to make a judgment about the value of Shapiro's categories.

II.

I agree with Shapiro's general premise, however, that we need more discriminating ways to describe administrative discretion. The traditional concept of "administrative discretion" is unsatisfactory for several reasons. First, as Shapiro notes, "administrative discretion" is a single unit of analysis. ${ }^{13}$ The dubious implication built into using a single category is that every exercise of discretion by an official shares something with every other exercise of discretion by an official. In addition, "administrative discretion" is a residual category - the weakest form of conceptual tool. The term tells us what something is not. If a matter is committed to administrative discretion, we know only that it is to be decided according to some body of lore foreign to judge-made law. ${ }^{14}$ Confiding certain decisions to administrative discretion implements the fundamental judgment, made explicitly by theorists of the New Deal such as James Landis, that the common law had become inbred and needed an infusion of ideas from other disciplines. ${ }^{15}$

It follows from this definition of administrative discretion-the power to decide according to principles foreign to judge-made law-that there is a fundamental tension between the ideal of administrative discretion on the one hand and judicial review on the other. Learned Hand pointed out that it is logically impossible for a court to review conclusions based on an agency's expertise-expertise that, by definition, the courts do not share-without invading the agency's discretion. ${ }^{16}$ Hand's point has been

11. See Ackerman, The Marketplace of Ideas, 90 YALE L.J. 1131, 1140 (1981).

12. Shapiro, supra note 3 , at 1500 .

13. Id. at $1488-89$.

14. See 5 U.S.C. $\$ 701$ (a)(2) (1982) (exempting actions "committed to agency discretion by law" from judicial review portions of Administrative Procedure Act). But see Citizens to Preserve Overton Park, Inc. v. Volpe, 401 U.S. 402, 413 (1971) (exemption inapplicable when there is "law to apply").

15. See Landis, Statutes and the Sources of Law, in HARVARD LEGAL ESSAYS 213, 213 (1934) ("traditional method of handling legal materials . . . feeds too much upon itself and offers strenuous resistance to . . . interpenetration" of knowledge from social sciences).

16. See NLRB v. Stow Mfg. Co., 217 F.2d 900, 905 (2d Cir. 1954) (L. Hand, J.), cert. denied, 348 U.S. 964 (1955):

The immunity of the Board's conclusions from judicial review . . . is a consequence of its putative specialized experience in the field of labor relations: an experience that is thought to enable it to appraise causes and consequences that escape the perception of those less widely acquainted with those relations. Thus, we accept the conclusions of a specialized tribunal, 
criticized, but not refuted. ${ }^{17}$ Hand went astray, however, by pushing a valid epistemological point to an uncharacteristically extreme and impractical conclusion: that judicial review should be abandoned. ${ }^{18}$ In reviewing administrative action, the legal system depends on strict logical consistency no more than it does in other areas. ${ }^{19} \mathrm{~A}$ degree of tension between judicial review and administrative discretion is tolerable, perhaps even desirable. The question is not whether courts can review administrative decisions without interfering with administrative discretion, but whether they can review without interfering unduly with discretion that Congress intended to confide to nonjudicial decisionmakers.

According to traditional doctrine, the inherent tension between judicial review and administrative discretion is ameliorated by positing a limited role for the courts; hence, the traditional verbal formulas: substantial evidence on the record as a whole, ${ }^{20}$ capricious, arbitrary, or an abuse of discretion. ${ }^{21}$ Finally, if Shapiro's reading of Citizens to Preserve Overton Park, Inc. v. Volpe ${ }^{22}$ is to be believed, there is now a third standard: clear error of judgment. ${ }^{23}$ These formulas have not always succeeded in keeping the friction between judicial review and administrative discretion within acceptable bounds. The conflict cannot be analyzed adequately on an all-

made upon evidence that would not prove them to an ordinary, or "lay," court, so to say.

17. See L. JAFFe, JUDiCiAL CONTROL OF ADMINISTRATIVE ACTION 613-15 (1965).

18. See NLRB v. Stow Mfg. Co., 217 F.2d at 905.

19. Gf. O. HOLMES, THE COMMON LAW 32 (M. Howe ed. 1963) ("law administered by able and experienced men, who know too much to sacrifice good sense to a syllogism").

20. See 5 U.S.C. $\S 706(2)$ (E) (1982).

21. See 5 U.S.C. $\$ 706(2)$ (A) (1982).

22. 401 U.S. 402 (1971). My principal purpose is not to quibble with Shapiro's premise that a different standard of review applies to informal, discretionary agency actions. One cannot, however, avoid mentioning that Shapiro's reading of Citizens to Preserve Overton Park v. Volpe, 401 U.S. 402 (1971), is questionable. Shapiro interprets Overton Park as establishing "clear error of judgment" as a distinct new "mood" or standard of review for informal or discretionary actions. Shapiro, supra note 3, at 1491. As a matter of textual analysis, Overton Park uses the phrase "clear error of judgment" to explain what is meant by the traditional standard of "arbitrary, capricious, an abuse of discretion, or otherwise not in accordance with law," 5 U.S.C. § 706(2)(A) (1982). "To make this finding the court must consider whether the decision was based on a consideration of the relevant factors and whether there has been a clear error of judgment." 401 U.S. at 416 (emphases supplied). Thus, in context, "clear error of judgment" is a gloss on "capricious and arbitrary," not an alternative to it.

Shapiro misreads the "clear error of judgment" language as establishing a standard different from "capricious and arbitrary" because he considers it implausible that courts would review informal, discretionary agency actions by the same standard that they use for $\S 553$ rulemaking. Shapiro, supra note 3, at 1491-94. Untidy, perhaps, but that is exactly how Overton Park has been read by the courts of appeals. See, e.g., American Mining Cong. v. Marshall, 671 F.2d 1251, 1254-55 (10th Cir. 1982) (applying Overton Park "clear error of judgment" test to informal rulemaking); Weyerhaeuser Co. v. Costle, 590 F.2d 1011, 1025 (D.C. Cir. 1978) (same); Action for Children's Television v. FCC, 564 F.2d 458, 478-79 (D.G. Cir. 1977) (same); American Meat Inst. v. EPA, 526 F.2d 442, 452-53 (7th Cir. 1975) (same); Portland Cement Ass'n v. Ruckelshaus, 486 F.2d 375, 402 (D.C. Cir. 1973), cert. denied, 417 U.S. 921 (1974) (same); see also 5 U.S.C. § 706(2)(A) (1982) (applying "arbitrary" and "capricious" standard to all "agency action"); cf. 5 U.S.C. $\$ 706(2)(\mathrm{E})$ (1982) (applying "substantial evidence" test only to proceedings subject to formal procedures under $\S \S 556-557$ ).

23. Shapiro, supra note 3, at 1493. 


\section{Comment on Shapiro}

or-nothing basis, as Hand attempted to do. Rather, the extent to which judicial review can be accomplished without undue interference with administrative discretion varies from one area of law to another depending on how divergent from, and incommensurable with, legal logic the sources of administrative discretion are.

I do not share Shapiro's assumption that the traditional administrative law categories-"substantial evidence," "capricious and arbitrary," or "clear error of judgment"-determine the stringency of judicial review. Judicial review varies from one substantive area to another, with the nature of the subject matter and the realities of the agency involved influencing the "mood" of judicial review far more than the characterization of the administrative action as adjudication, rulemaking, or informal action. ${ }^{24}$ Courts should be hesitant to second-guess agency risk assessments, not because a matter involves rulemaking rather than adjudication, but because the agency's exercise of discretion is based in part on technical evidence which judges rarely understand. The occasional court decision in the environmental area that has set aside an administrative decision for a "clear error of judgment" in assessing technical evidence has usually been based on judicial ignorance of epidemiology, toxicology, or some other "ology."25 The problem is not so much that judges misunderstand the facts as it is that they lack the background knowledge and norms of judgment to interpret the facts sensibly. Moreover, judicial review of agency decisions in scientific and technical areas has proved troublesome not only because courts have interfered when they should not have, but also because courts have proved incapable of intervening when agency decisions were grossly defective and should have been reexamined. ${ }^{26}$

24. See B. ACKERMAN \& W. HASSLER, CLEAN COAL/DIRTY AIR 113 (1981) (court should not invalidate agency action for procedural shortcomings in notice-and-comment rulemaking when any "reader of the weekly BNA Environmental Reporter" would be able to follow EPA's changes); see also Sierra Club v. Costle, 657 F.2d 298, 355 n.213 (D.C. Cir. 1981) (citing Ackerman and Hassler with approval).

Presumably, the converse should also hold true: In areas which lack effective, informal channels of communication such as the BNA Environmental Reporter, a court should place greater stress on ensuring that interested parties receive notice through official rulemaking procedures.

25. E.g., Gulf South Insulation v. Consumer Prods. Safety Comm'n, 701 F.2d 1137 (5th Cir. 1983); Ethyl Corp. v. EPA, 541 F.2d 1 (D.C. Cir.) (en banc), cert. denied, 426 U.S. 941 (1976).

Most commentators conclude that courts are not competent to review scientific and technical evidence. See Jasanoff \& Nelkin, Science, Technology, and the Limits of Judicial Competence, 68 A.B.A. J. 1094 (1982); Yellin, High Technology and the Courts: Nuclear Power and the Need for Institutional Reform, 94 HARV. L. REV. 489 (1981).

26. See B. ACKERMAN \& W. HASSLER, supra note 24, at 20 (EPA's previous "nartow" and "mechanical" readings of $\S 111$ of Clean Air Act not remedied by judicial review). Even after Ackerman and Hassler exposed EPA's new source-performance standard for coal-fired power plants as "inept," $j d$. at 2, judicial review proved unequal to the task of invalidating it. See Sierra Club v. Costle, 657 F.2d 298, 316 n.38 (D.C. Cir. 1981) ("several significant statutory questions" raised by Ackerman and Hassler remain undecided because "no party has raised them"). The court declined to intervene despite indications that extraneous political factors, such as a threat by Senator Byrd to 
In the final analysis, administrative discretion and judicial review pull in opposite directions. One can imagine greater emphasis on administrative discretion and government by "technocracy" in the future or more court-imposed rules to control administrative discretion, but not both simultaneously.

\section{III.}

This brings me to the heart of my disagreement with Shapiro. Underlying Shapiro's proposed categories is the premise that it is appropriate to analyze administrative discretion from the Olympian perspective of an administrative law that transcends particular agencies and statutes to embrace broad categories of administrative action. ${ }^{27}$ I am not convinced. I doubt whether the traditional conception of administrative law as "embrac[ing] all governmental machinery for carrying out government programs"28 remains viable (if it ever was). Certainly there is a labor law, a law of social security and entitlement programs, an environmental law, and so on. What I question is whether it makes sense to think in terms of a unitary, overarching "trans-substantive" administrative law that controls all governmental decisionmaking. ${ }^{29}$

withdraw his support for the SALT treaty, had influenced EPA's decision. See id. at 390 n.450 (denying discovery into communications relating to political factors); id. at 409 n.539 (holding newspaper reports of "hints" of political factors insufficient to invalidate regulation); $c$. B. ACKERMAN \& W. HASSLER, supra note 24, at 114-15 ("problem with Byrd's intervention was not procedural but substantive"; it and other indications of "mindless decision making" "demand a strong remand to the administrator").

27. In the published version of his Article, Shapiro seems to adopt the thrust of this Comment by concluding: "It is distressingly clear to teachers of administrative law that they may have no subject matter to teach, that administrative procedure may be determined largely by the agency or even the policy involved. I certainly do not expect a uniform judicial or congressional reaction to the many forms of discretion." Shapiro, supra note 3, at 1522. He does not, however, explain how a "policyspecific" perspective can be made consistent with his proposed categories for conceptualizing administrative discretion.

28. K. DAVIS, ADMINISTRATIVE LAW $\S 1.01$, at 2 (3d ed. 1972); see S. BREYER \& R. STEWART, ADMINISTRATIVE LAW AND REGULATORY POLICY 11 (1979):

Administrative law as traditionally understood ... deals with ... general principles and rules that cut across the particular substantive fields and potentially embrace all forms of administrative activity.

Administrative law defined in this global sense is found primarily, although not exclusively, in the decisions of courts reviewing the validity of administrative actions in judicial proceedings instituted by private citizens.

See also L. JAFFE, JUDICIAL Control OF ADMINISTRATIve ACTION, supra note 17 (emphasis supplied); Shapiro, On Predicting the Future of Administrative Law, REGULATION, May/June, 1982, at 19 (defining administrative law as "a series of legal doctrines through which courts police the jurisdictional boundaries and decision-making processes of regulating agencies").

29. Cf. Freedman, The Uses and Limits of Remand in Administrative Law: Staleness of the Record, 115 U. PA. L. REV. 145, 147 (1966) (framing generalized rules of administrative law is a "hazardous enterprise"); Rabin, Administrative Law in Transition: A Discipline in Search of An Organizing Principle, 72 Nw. U.L. REV. 120, 136 (1977) (questioning whether there is a generalized administrative process as opposed to specific understandings of particular agencies).

I borrow the term "trans-substantive" from Cover, For James Wm. Moore: Some Reflections on a 
As a purely descriptive matter, courts rarely cite labor cases in environmental cases anymore. ${ }^{30}$ Few scholars write on administrative law catholically. Even when they generalize, most scholars today tend to write from a perspective formed by a particular sub-specialty such as environmental law or the law of social welfare programs. ${ }^{31}$

These trends reflect a significant difference between the actual relationship that has evolved between courts and administrative decisionmakers, and what early theorists of administrative law assumed that the relationship would be. Earlier, I termed the conflict between the theory and the reality of administrative law the "dis-integration" of administrative law. ${ }^{32}$ I hope that this inflammatory term captures two related ideas: first, that the courts have proved unable to coordinate and harmonize exercises of administrative discretion, ${ }^{33}$ and second, that the law of administrative decisionmaking is fragmenting into separate subdomains that have less and less influence on one another.

Thus, Shapiro and I fundamentally disagree about where administrative law is headed. Shapiro's predictions for the "next stage" of administrative law are based on a combination of outside forces and the internal dynamics of administrative law. ${ }^{34} \mathrm{I}$ agree that law grows in response to both. ${ }^{38} \mathrm{I}$ am even willing, for purposes of argument, to accept Shapiro's assumption that we are moving into a new technocratic episode ${ }^{36}$ in the "technocratic-democratic cycle." Where he and I differ is in our under-

Reading of the Rules, 84 YALE L.J. 718 (1975) (discussing innovation of single code of procedural rules for federal courts).

30. But cf. City of Milwaukee v. Illinois, 451 U.S. 304, 316 (1981) (citing San Diego Bldg. Trades Council v. Garmon, 359 U.S. 236 (1959) (labor case)).

This exception also proves the point. The issue in both cases, pre-emption, is a peripheral one for both environmental and labor law. Borrowing is to be expected in border areas in which indigenous policies are not yet well developed. See infra pp. 1532-33 (discussing effect of "critical mass" of cases).

31. See Stewart, The Reformation of American Administrative Law, 88 HARV. L. REV. 1667 (1975).

32. But see supra p. 1524 (cautioning against the creation of private languages).

33. As late as the 1960's, commentators still expressed this as an aspiration of judicial review. See L. JAFFE, supra note 17, at 327 (courts should review agency action to bring agency action "into harmony with the totality of the law" and to guarantee "the integrity of the legal system").

34. In attempting to describe the "internal dynamics" that are influencing the growth of administrative law, both Shapiro and I are part of a developing evolutionary tradition in legal scholarship. See Clark, The Interdisciplinary Study of Legal Evolution, 90 YALE L.J. 1238 (1981); Clark, The Morphogenesis of Subchapter C: An Essay in Statutory Evolution and Reform, 87 YALE L.J. 90 (1977).

35. See Elliott, supra note 9, at 142 (describing "internal" and "external" selection in the common law); see also Fiss, Objectivity and Interpretation, 34 STAN. L. REV. 739, 748-50 (1982) (contrasting "internal perspective" on legal issues with moral, political and religious judgments by "external critic," but noting that law can "evolve" in response to external factors).

36. Shapiro, supra note 3 , at 1497-99.

37. Id. at 1497-98. But see Crandall \& Lave, Introduction and Summary, in THE SCIENTIFIC BASIS OF HEALTH AND SAFETY REgulation 1, 16 (R. Crandall \& L. Lave eds. 1981) (in the five cases of health and safety regulation studied, technical information was not sole basis for setting standards and often not even important factor). 
standings of the nature of the "internal dynamic" influencing the course of administrative law. Shapiro argues that the historical trend in administrative law is toward greater judicial control over administrative discretion-first, over adjudication; then, over rulemaking; and, in the future, over informal, discretionary action. ${ }^{38} \mathrm{I}$ believe that Shapiro is incorrect on two counts, one historical and the other institutional.

As an historical matter, the high-water mark of judicial control of administrative action was reached about a decade ago with cases such as Citizens to Preserve Overton Park, Inc. v. Volpe $e^{39}$ and Association of Data Processing Service Organizations v. Camp. ${ }^{40}$ These and other decisions of the middle 1970's marked the culmination of the most recent wave of agency creation. ${ }^{11}$ The "struggle for judicial supremacy"12 was complete once Overton Park brought informal, discretionary administrative actions within the reviewing power of the courts and once the Court of Appeals for the D.C. Circuit developed techniques for reviewing informal rulemaking.

But the culmination of one style necessarily sets the stage for the next. ${ }^{43}$ Since the mid-1970's, the direction of legal development has changed. During the last decade, the Supreme Court has sharply restricted the tools available to reviewing courts. The pendulum had clearly begun to swing away from judicial control and toward greater administrative autonomy in Train v. Natural Resources Defense Council, ${ }^{44}$ in which the Supreme Court held that a reviewing court cannot overrule an agency for what the court believes is a mistake in interpreting the law; the court must defer to

38. Shapiro, supra note 3 , at $1488,1519$.

39. 401 U.S. 402 (1971) (expanding range of administrative decisions subject to judicial review to include informal agency actions).

40. 397 U.S. 150 (1970) (expanding range of persons with standing to initiate judicial review of administrative actions).

41. There have been three waves of agency creation: (1) the creation of regulatory agencies such as the ICC during the Progressive era, see S. BREYER \& R. STEWART, supra note 28, at 23-24; (2) the creation of the New Deal agencies, such as the NLRB and the SEC, which expanded federal regulation of the economy, id. at 26-28; and (3) the creation of the new "Social Regulation" of the 1970's, which expanded federal regulation of health and safety through agencies such as EPA, OSHA, and the Consumer Products Safety Commission, see Schuck, The Politics of Regulation (Book Review), 90 YALE L.J. 702, 707 (1981) (at least 30 important regulatory statutes enacted between 1970 and 1975, creating new agencies and expanding jurisdiction of existing ones).

Each round of agency creation has provoked changes in prevailing concepts of administrative law. See S. BREYER \& R. STEWART, supra note 28, at 23-35; see also Environmental Defense Fund v. Ruckelshaus, 439 F.2d 584, 597-98 (D.C. Cir. 1971) (proclaiming "new era" in relationship between courts and agencies).

42. I borrow this phrase from Robert Jackson. See R. JAGkSON, THE STRUGgLe For Judicial SUPREMACY: A CRISIS IN AMERICAN POWER POLITICS (1941).

43. Cf. Deutsch, Neutrality, Legitimacy, and the Supreme Court: Some Intersections Between Law and Political Science, 20 STAN. L. REV. 169, 206 (1968) ("the culmination of an old style" is also "the beginning of a new perspective"); T. KuHN, supra note 2, at 93 (revolutionary scientific discovery such as x-rays "necessarily violated one paradigm as it created another").

44. 421 U.S. 60 (1975). 


\section{Gomment on Shapiro}

the agency's interpretation of statutory language and legislative history if it is "reasonable." Vermont Yankee Nuclear Power Corporation v. Natural Resources Defense Council ${ }^{46}$ further limited the judiciary's power by holding that a court reviewing an administrative action may not impose additional procedural requirements if an agency, in the exercise of its discretion, has chosen not to require such procedures. The judiciary can no longer pioneer the development of administrative procedures-as the D.C. Circuit did in the area of informal rulemaking in the early 1970's. ${ }^{47}$ Most recently, the Court has indicated that it may be impermissible for federal judges to develop common law in areas touched by comprehensive regulatory statutes: Administrative discretion to make law is exclusive. ${ }^{48}$ Thus, the Supreme Court's direction in the dozen years since Overton Park does not support Shapiro's belief in the continuing expansion of judicial control over administrative discretion.

If only recent Supreme Court decisions were at issue, the "disintegration" of a unitary, court-made administrative law might be written off as a passing phase, or one of Professor Rabin's oscillations which is likely to reverse itself as soon as a few new Justices are appointed. There are, however, deeper institutional factors that suggest that the trend will continue.

As the administrative state matures, the locus of power naturally shifts from court-imposed administrative law, which was central during the formative era, toward particularized statutory goals and policies that are elaborated primarily by agencies. To some degree, the shift can be attributed to the sheer volume of administrative activity. Once an area of law reaches a certain "critical mass," the need to borrow concepts from outside decreases and the field moves toward greater self-sufficiency. The process resembles the way in which a natural species is formed as animals lose the ability to crossbreed. 48

A second process is at work as well. As the mass of statutes, regulations, and cases continues to grow beyond a certain point (defined perhaps by the amount of information that an Arthur Corbin or Kenneth Culp Davis can absorb in a lifetime), ${ }^{50}$ lawyers and judges can no longer relate

45. Id. at 75; accord Chevron, U.S.A. v. Nat'l Resources Defense Counsel, 104 S. Ct. 2778, 2782 (1984).

46. 435 U.S. 519 (1978).

47. See Shapiro, supra note 3 , at 1488 .

48. See City of Milwaukee v. Illinois, 451 U.S. 304 (1981) (congressionally established regulatory program preempted federal common law of water pollution); Middlesex County Sewerage Auth. v. National Sea Clammers Ass'n, 453 U.S. 1 (1981) (no private rights of action authorized under water pollution legislation). But see Nader v. Allegheny Airlines, 426 U.S. 290 (1976) (regulatory authority of $\mathrm{CAB}$ does not preclude action for common law fraud).

49. See M. WHITE, MODES OF SPECIATION (1978).

50. For a stimulating discussion of the relationships between forms of legal writing and the ways 
all the parts to one another. They begin to think in terms of separable fields of law. Gradually, an NLRB case just seems less binding on an environmental case. Through a kind of centrifugal force, a number of administrative subdomains gradually form, each having its own internal integrity. The boundaries are neither firm nor exact, but they are there. Ironically, the success and expansion of the administrative state leads naturally to the "dis-integration" of administrative law.

I am not saying that administrative law no longer exists in a literal sense; standing, notice-and-comment rulemaking, and all the rest are, of course, still with us. Rather, my point is that the center of gravity has shifted away from the broad, overarching generalizations of the administrative law of the 1960's toward more particularistic statutory and policy objectives. $^{51}$ This phenomenon is not unique to administrative law; it occurs in many bodies of law as they mature.

Let me give a practical example. I see the Supreme Court's recent pronouncements in the Benzene case ${ }^{62}$ concerning the evidentiary burden that an agency must satisfy before regulating a carcinogen as having, at most, precedential value in the environmental area. ${ }^{53} \mathrm{I}$ question whether this case, or most other current opinions involving administrative decisions, can be generalized across so broad a category as all "informal rulemaking" cases. ${ }^{54}$

This trend toward the fragmentation of administrative law can also be seen at the statutory level. Instead of revising the 1946 Administrative Procedure Act (APA), ${ }^{\text {s5 }}$ Congress has written separate procedural codes

that lawyers view the law, see Simpson, The Rise and Fall of the Legal Treatise: Legal Principles and the Forms of Legal Literature, 48 U. CHI. L. REV. 632 (1981).

Simpson ascribes the decline of treatise writing in part to "a significant decline in the belief that legal principles . . . are of universal validity." Id. at 667. He also mentions America's "rising bulk of legal material, particularly law reports" as an impediment to the treatise-writing tradition. Id. at 676.

The argument in the text of this Comment is related, but proposes that the forms of legal literature not only are influenced by, but also influence the way that lawyers and judges conceive of the law.

51. Cf. Editors' Preface to Stewart \& Sunstein, Public Programs and Private Rights, 95 HARV. L. REV. 1195, 1195 (1982) (advocating judicial creation of remedies "linked with particular conceptions of the deepest purposes particular statutes are meant to advance").

52. Industrial Union Dep't v. American Petroleum Inst., 448 U.S. 607 (1980).

53. It is plausible to read the benzene case, even more narrowly, as reflecting the particular balance struck by Congress between risks to health and economic well-being in the workplace. See 448 U.S. at 642-52 (reviewing statutory language and legislative history of OSHA); see also Industrial Union Dep't v. Hodgson, 499 F.2d 467, 478 (D.G. Cir. 1974) ("Congress does not appear to have intended to protect employees by putting their employers out of business. . .."). The weighing of competing values may be different under other statutes regulating environmental hazards. See American Textile Mfrs. Inst. v. Donovan, 452 U.S. 490, 510 \& n.30 (1981) (Cotton Dust) (reviewing other environmental statutes that provide a different role for economic considerations).

54. But see Shapiro, supra note 3, at 1506, interpreting the benzene case as illustrating the use of burdens of proof by courts to control administrative discretion within the broad category, "thematic statutes." A similar idea was proposed in Leventhal, Environmental Decisionmaking and the Role of the Courts, 122 U. PA. L. REV. 509, 535-536 (1974).

55. 5 U.S.C. $\S \S 551-559,701-706$ (1982). 


\section{Comment on Shapiro}

into the organic acts establishing agencies and programs-creating a series of "mini-APAs." I I suspect that Congress will continue to create procedures tailored to the particular needs of various substantive areas through separate statutes, rather than rewriting the APA so as to impose a unitary procedural code, as Shapiro predicts..$^{57}$ Of course, "dis-integration" does not mean that the D.C. Circuit is about to go out of business. On the contrary, its task is becoming more challenging. In place of a single, unitary administrative law, we now have a series of administrative laws, which are developing more or less independently of one another.

As a result of these changes in the nature of administrative law, I doubt that we can make useful generalizations about "moods" of judicial review applicable across broad procedural categories of cases, as Shapiro suggests. ${ }^{58}$ What actually constitutes "substantial evidence" in environmental cases no longer bears much resemblance to what goes by the same name in labor or rate-making cases. ${ }^{\text {s9 }}$

I must also confess some skepticism about the method that Shapiro uses in the early part of his Article to analyze different standards of judicial review. To the extent that productive generalizations can be made about categories as broad as all informal administrative action, one has to go beyond an analysis of the wording of legal "standards" to study actual behavior, as Shapiro and other political scientists have demonstrated over the years. I doubt that empirical study would bear out Shapiro's suggestion that informal agency action is now reviewed at the most demanding point on the spectrum. Nor is this problem avoided by recasting the subject of the generalization as only a "mood," not a rule.

\section{IV.}

Let me add a word or two about the implications for lawyers of the changes I have been describing. The causes of the "dis-integration" of administrative law, about which many others at the Symposium have spoken, are related to the rise of the activist state and public law. As long as we viewed administrative law as involving disputes between an individual and a governmental official-a tradition that goes back to Marbury $v$.

56. Compare, e.g., 42 U.S.C. $\$ 7607$ (d) (1982) (procedure under the Clean Air Act) with 15 U.S.C. $\S 2605$ (c) (1982) (procedures under Toxic Substances Control Act).

57. Shapiro, supra note 3 , at 1488.

58. Id. at $1490-91$.

59. See Environmental Defense Fund v. EPA, 598 F.2d 62, 82-83 (D.C. Cir. 1978) (PCBs) (describing modifications of substantial evidence test as developed "in review of nonscientific adjudications" which are necessary to adapt it to "review of scientific rulemaking"); Industrial Union Dep't v. Hodgson, 499 F.2d 467, 473-74 (D.C Cir. 1974) (discussing difficulty of adapting traditional substantial evidence test to risk assessments that involve elements of legislative policy). 
Madison $^{60}$ and Ex parte Young ${ }^{61}$-it made sense to fashion an administrative law along the lines of judicial procedure, with emphasis on formal regularity, fairness to individuals, and confining decisionmakers within the scope of their authority. ${ }^{62}$ As a "public law" or "activist state" conception emphasizing implementation of policy to improve the general welfare $^{63}$ gradually supplants the dispute resolution model, the courts' claim to fashion a unitary "administrative law" is undermined. Courts and lawyers may be experts at assessing fairness to individuals; they hold no special brief in fashioning policies to serve the general welfare. ${ }^{64}$

Now, and increasingly in the future, there will be less law and more administration in administrative law. The ambitions-perhaps it would be more accurate to say the conceits-proposed for judicial review by an earlier generation of administrative lawyers have failed. Louis Jaffe, for example, believed that courts could impose a system of administrative law that would bring integrity and coherence to administrative decisions and proclaim the premise that agencies would be "brought into harmony with the totality of the law . ..." Jes Jaffe's image of courts as supervising, coordinating, and integrating administrative action is irreconcilable with Landis' vision of politics and expertise, not common law logic, guiding the exercise of administrative discretion. Landis, not Jaffe, has been borne out by history. Today, the function of coordinating and integrating exercises of administrative discretion is no longer being performed primarily by courts. Instead, new forms have emerged to fill the vacuum. The Office of Management and Budget now wields power far greater than any court's over the substance of agency decisions. ${ }^{B B}$ Until recently, the legislative veto gave broad supervisory power to committees of Congress. ${ }^{67}$ In addition, a

60. 5 U.S. (1 Cranch) 137 (1803).

61. 209 U.S. 123 (1908).

62. See DeLong, Informal Rulemaking and the Integration of Law and Policy, 65 VA. L. REV. 257,339 (1979) (difficulty of adapting traditional "basic concepts" of "conflicts between individuals" and "procedural fairness" to broad government policymaking); Stewart \& Sunstein, supra note 51, 1202-03 (traditional model of administrative law as "private rights of defense").

63. See Mashaw, supra note 5, at 1153-73 (public law model as implementation of general welfare).

64. See Shapiro, supra note 28 , at 25 ("Having levered themselves off the grounds of procedure where they have special claims of expertise and onto the grounds of highly technical substance where they do not, courts will find themselves claiming to exercise a kind of review for which they have neither the capacity nor the legitimacy.").

65. See L. JAFFE, supra note 17 , at 327.

66. See Exec. Order No. 12,291, 3 C.F.R. 127 (1981); Note, Regulatory Analyses and Judicial Review of Informal Rulemaking, 91 YALE L.J. 739, 746-49, 753-57 (1982).

67. Although not a new invention, the use of the legislative veto expanded dramatically in the last decade. See J. SUNDQUIST, THE DECLINE AND RESURGENGE OF CONGRESS 344-66 (1981). The legislative veto was held unconstitutional in Immigration \& Naturalization Service v. Chadha, $103 \mathrm{~S}$. Ct. 2764 (1983). For a discussion of the legislative veto and possible substitutes, see Elliott, INS v. Chadha: The Administrative Constitution, the Constitution, and the Legislative Veto, 1983 SUP. CT. REV. 125, 156-61. 
number of specialized review institutions, such as the Science Advisory Board within the Environmental Protection Agency, ${ }^{68}$ have evolved to constrain administrative discretion, the role that Jaffe and his contemporaries claimed as the natural inheritance of courts and the system of administrative law.

What I have been calling the "dis-integration" of administrative law does not mean that administrative lawyers must abdicate in an activist state. ${ }^{6 \theta}$ It does mean, however, that judicial review and the procedural arsenal of the administrative lawyer of the 1960's are no longer sufficient. In place of judicial review under the Administrative Procedure Act, the primary tools of an administrative lawyer's trade are increasingly a variety of new techniques for controlling administrative discretion: actions for damages and injunctive relief; ${ }^{70}$ the Freedom of Information Act; ${ }^{71}$ advisory committees; ${ }^{72}$ legislative oversight; ${ }^{73}$ and cost-benefit analyses by the Office of Management and Budget. ${ }^{74}$

Now and in the future, administrative lawyers must master new skills so that they can represent their clients before legislative committee staffs, in technical policy formulation, in the substance of administrative rulemakings, and in inter-agency reviews within the Executive Branch. This requires not only that lawyers acquire a speaking knowledge of economics and politics, but also that they overcome their "technophobia" and become comfortable making arguments in the technical languages of administrative discretion as well as the legalistic language of administrative law. ${ }^{78}$

Assuming that the legal profession meets these challenges, ${ }^{76}$ lawyers

68. 42 U.S.C. $§$ 4365(e) (1982); see GENERAL ACCOUNTING OFFICE, IMPROVING THE SCIENTIFIC AND TECHNICAL INFORMATION AVAILABLE TO THE ENVIRONMENTAL PROTECTION AGENCY IN ITS DECISIONMAKING PROCESS 24-27 (1979) (concluding that review by Science Advisory Board had "significant effect" on EPA's criteria document for lead standards). But see American Petroleum Inst. v. Costle, 665 F.2d 1176, 1188 (D.G. Cir. 1981), cert. denied, 455 U.S. 1034 (1982).

69. See Ackerman, supra note 6.

70. 42 U.S.C. $\S 1983$ (1982). See generally P. SCHUCK, SUING GOVERNMENT: CITIZEN REMEDIES FOR OFFICIAL WRONGS (1983)(discussing public tort remedies).

71. 5 U.S.C. $\$ 552$ (1982). During the discussion at the Symposium, Professor Michael Graetz pointed out that the Freedom of Information Act constrains agency discretion.

72. See Federal Advisory Committee Act, 5 U.S.C. app. I (Supp. I, 1977).

73. See J. SUNDQUIST, supra note 67 , at $315-43$.

74. See supra note 70 .

75. See DeLong, How to Convince An Agency: A Handbook for Policy Advocates, Regulation, Sept./Oct. 1982, at 27.

76. Some portions of the legal profession have been slow to adapt to changes in the nature of administrative law. See DeLong, supra note 62, at 338-39:

In a powerful way, once an issue becomes nonreviewable it automatically is transformed into "nonlaw," and, lacking a base of operations in the courts, the legal profession seems to conclude that the lawyer qua lawyer has no business concerning himself with the issue. Thus there has been little interest in the development of systematic legal approaches to policy decisions, despite the continuing involvement of Washington lawyers, at least, in such decisions. This participation in policymaking seems to be regarded with embarrassment as influence 
will continue to play a major role in designing the programs of the activist state. ${ }^{77}$ But we should not overlook the equally important role for lawyers in mediating between a technocratic, activist state and individuals' claims of right. In our enthusiasm for the activist state, we should never lose sight of the traditional aspiration of lawyers to protect individual rights. This mission does not evaporate in an activist state; it only becomes less popular.

peddling or lobbying, and few people write articles or teach courses on how to engage in these activities more effectively.

77. Cf. Ackerman, supra note 6, at 1088-90 (lawyers as central actors in activist governance). 